\title{
Waste glass as binder in alkali activated slag-fly ash mortars
}

\author{
G. Liu $(\mathbb{D} \cdot$ M. V. A. Florea • H. J. H. Brouwers
}

Received: 22 May 2019/ Accepted: 24 September 2019/Published online: 3 October 2019

(C) The Author(s) 2019

\begin{abstract}
This paper illustrates the application of waste glass powder as part of the binder in slag-fly ash systems activated by $\mathrm{NaOH}$ and $\mathrm{NaOH} / \mathrm{Na}_{2} \mathrm{CO}_{3}$ activators. To evaluate the reaction kinetics, reaction products, mechanical properties, and durability performance of glass powder modified alkali activated slag-fly ash systems, calorimetry test, X-ray diffraction, FTIR, strength test, drying shrinkage tests, and carbonation test were conducted. From the isothermal calorimeter results, glass powder shows a higher reactivity compared to fly ash but still lower than slag. The reaction products of glass power modified samples exhibit an enhancement of polymerization degree of $\mathrm{Si}-\mathrm{O}-\mathrm{T}$, observed in FTIR. As a consequence, higher drying shrinkage exists in glass modified mortars. The mechanical performance of different samples is mostly controlled by the $\mathrm{Ca} / \mathrm{Si}$ of dry mixtures and activator type. After the slag-fly ash binder system was modified by the waste glass, a significant enhancement of resistance to carbonation was identified, especially for $\mathrm{NaOH} / \mathrm{Na}_{2} \mathrm{CO}_{3}$ activated mortars, which show an increase of $300 \%$ on the carbonation resistance ability compared to the reference sample. The $\mathrm{Na} /(\mathrm{Si}+\mathrm{Al})$ ratio of dry mixtures
\end{abstract}

G. Liu ( $\varangle)$ · M. V. A. Florea · H. J. H. Brouwers Department of the Built Environment, Eindhoven University of Technology, P.O. Box 513, 5600 MB Eindhoven, The Netherlands e-mail: G.Liu@tue.nl exhibits a positive correlation with carbonation resistance.

Keywords Alkali activation - Slag-fly ash binder . Waste glass · Reaction kinetics · Carbonation

\section{Introduction}

The cement production consumes a large quantity of energy and natural resource every year to meet the global demand for construction. $120-160 \mathrm{kWh}$ of energy and $1.5 \mathrm{t}$ of raw materials are consumed for 1 ton of cement production [1]. In recent years, supplementary cementitious materials (SCM), such as GGBS, fly ash, silica fume and waste glass have attracted more attention as ingredients in concrete manufacture, combined with OPC [2, 3]. However, the application of SCMs mostly relies on the pozzolanic reaction with the hydration products of cement clinkers [4-6]. In some studies, the addition of SCMs even causes negative effects on the performance of conventional concrete $[7,8]$. For the purpose of energy conservation and environment protection, alkali activated concrete-a kind of clinker free building material—has been studied for several years.

Ground granulated blast furnace slag (GGBS) and fly ash are usually applied in the production of alkali activated concrete. For example, GGBS can be used 
for providing $\mathrm{Ca}$ and $\mathrm{Si}$ in the high calcium binder system in normal alkali activated materials, the reaction product being mainly $\mathrm{C}-\mathrm{A}-\mathrm{S}-\mathrm{H}$ [9]. Fly ash can usually be the main binder in low calcium geopolymer concrete production, the $\mathrm{N}-\mathrm{A}-\mathrm{S}-\mathrm{H}$ being the main reaction production $[10,11]$. Alkali activated GGBS shows a high shrinkage, which causes the volumetric stability problem [12]. Moreover, during the production of fly ash based geopolymer, high temperature curing is always needed [13]. Combining GGBS and fly ash in alkali activated binder systems is helpful to compensate the negative effects induced by each other. Some studies revealed that the incorporation of fly ash in alkali activated slag samples can significantly improve the shrinkage during the reaction [14-16]. Furthermore, the blended binder exhibits an excellent performance of strength and durability [17].

In recent years, recycled waste glass has attracted more attention in case of the sustainable application in building materials. Since waste glass contains a high amorphous content of silica, a potential of pozzolanic reaction has been identified [18]. Some studies reported applying waste glass as SCM in conventional concrete, the microstructure improvement was identified [5, 19]. In previous studies, waste glass was also used as ingredient, combining with GGBS or fly ash for the alkali activated concrete production, such as a binder, or even activator to replace water glass [20-23]. Sodium hydroxide, water glass and sodium carbonate are commonly applied as activators in alkali activated concrete production. It has been identified that waste glass shows a higher dissolution rate in a $\mathrm{NaOH} / \mathrm{Na}_{2} \mathrm{CO}_{3}$ solution compared to $\mathrm{NaOH}$ solution at the same sodium concentration [20]. In addition, the blended activator $\mathrm{NaOH} / \mathrm{Na}_{2} \mathrm{CO}_{3}$ was reported to induce better performance of GGBS-glass systems [23]. In some reports, the waste glass powder in alkali activated concrete can play a role similar to water glass in microstructure enhancement [22]. As well known, the selection of binder composition and activator of alkali activated concrete can cause huge influences on the concrete durability performance. It has been reported that the higher silicate modulus of activator provides a higher resistance to carbonation of alkali activated slag [24]. However, compared to the water glass, the influence of waste glass as binder in alkali activated slag-fly ash system on mechanical and durability performance by using different activators is still not clear. Therefore, the application of waste glass in slag-fly ash alkali activated system still needs more focus. The activator types, reaction mechanism, mechanical and durability performance need further study.

The present study evaluates the application of waste glass in slag-fly ash alkali activated binder systems. The waste glass was used to replace slag, fly ash or total of the binder by $20 \%$, to study the influences of waste glass on slag-fly ash binder system. Two kinds of activators $\left(\mathrm{NaOH}\right.$ and $\left.\mathrm{NaOH} / \mathrm{Na}_{2} \mathrm{CO}_{3}\right)$ were selected. The reaction kinetics, reaction products, strength performance and durability properties are studied. The purpose is to optimize the application of waste glass in a slag-fly ash binder.

\section{Materials and methods}

\subsection{Materials characterization}

The recycled waste glass fractions (mixed colour) were supplied by a glass recycling plant. Then, a ball mill was used to ground it into a fine powder. Ground granulated blast furnace slag (GGBS) was supplied by ENCI, IJmuiden, Netherlands. Class F fly ash was supplied by Vliegasunie, the Netherlands. Table 1 shows the chemical composition of waste glass, GGBS and fly ash. The XRD of raw materials is shown in Fig. 1. The particle size distributions of recycled waste glass powder, GGBS, fly ash, and sand are shown in Fig. 2.

\subsection{Test methods}

\subsubsection{Activators and mortars preparation}

The $\mathrm{NaOH}$ activator solution was prepared using sodium hydroxide pellets $(\mathrm{NaOH})$ and distilled water to achieve a concentration of $8 \mathrm{M}$. The blended $\mathrm{NaOH}-\mathrm{Na}_{2} \mathrm{CO}_{3}$ (50:50 by mass) activator was prepared from sodium hydroxide pellets $(\mathrm{NaOH})$, sodium carbonate $\left(\mathrm{Na}_{2} \mathrm{CO}_{3}\right)$ and distilled water, which also keeps the same Na dosage of $8 \mathrm{M}$. The sample mix design and the initial $\mathrm{Ca} / \mathrm{Si}$ and $\mathrm{Na} /(\mathrm{Si}+\mathrm{Al})$ of dry mixtures are shown in Table 2. The equivalent $\mathrm{Na}_{2} \mathrm{O} \%$ for all binders is kept at of a constant dosage of $10 \%$. 
Table 1 Chemical composition of recycled glass, GGBS and fly ash

\begin{tabular}{|c|c|c|c|}
\hline Chemical composition & Waste glass & GGBS & Fly ash \\
\hline $\mathrm{Na}_{2} \mathrm{O}$ & 14.65 & - & - \\
\hline $\mathrm{MgO}$ & 1.30 & 8.57 & 1.14 \\
\hline $\mathrm{Al}_{2} \mathrm{O}_{3}$ & 1.93 & 13.21 & 26.98 \\
\hline $\mathrm{SiO}_{2}$ & 68.33 & 29.41 & 51.44 \\
\hline $\mathrm{SO}_{3}$ & 0.09 & 2.64 & 1.12 \\
\hline $\mathrm{K}_{2} \mathrm{O}$ & 0.70 & 0.42 & 1.84 \\
\hline $\mathrm{CaO}$ & 11.90 & 42.67 & 5.83 \\
\hline $\mathrm{TiO}_{2}$ & 0.06 & 1.49 & 1.78 \\
\hline $\mathrm{Cr}_{2} \mathrm{O}_{3}$ & 0.12 & 0.001 & 0.03 \\
\hline $\mathrm{MnO}$ & 0.02 & 0.40 & 0.06 \\
\hline $\mathrm{Fe}_{2} \mathrm{O}_{3}$ & 0.36 & 0.37 & 8.27 \\
\hline $\mathrm{ZnO}$ & 0.01 & - & 0.02 \\
\hline $\mathrm{BaO}$ & 0.06 & 0.08 & - \\
\hline $\mathrm{PbO}$ & 0.05 & - & 0.010 \\
\hline $\mathrm{P}_{2} \mathrm{O}_{5}$ & - & - & 0.85 \\
\hline $\mathrm{Cl}$ & 0.02 & 0.01 & - \\
\hline Specific density $\left(\mathrm{g} / \mathrm{cm}^{3}\right)$ & 2.51 & 2.93 & 2.30 \\
\hline Specific surface area $\left(\mathrm{m}^{2} / \mathrm{g}\right)$ & 0.99 & 0.37 & 0.82 \\
\hline LOI & 1.34 & 1.15 & 2.27 \\
\hline
\end{tabular}

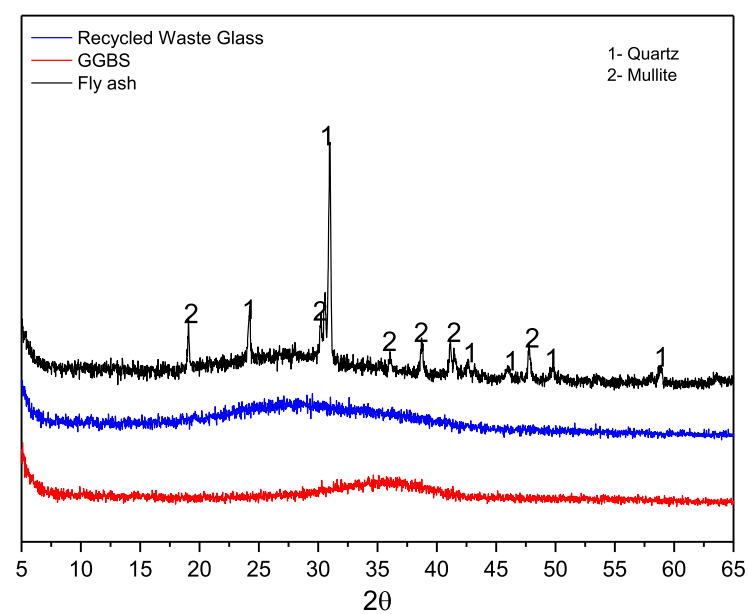

Fig. 1 XRD patterns of all materials employed as binder

The mixing of mortars was done by using a 5-1 Hobart mixer. At first, mixing the dry slag-fly ashwaste glass binders and fine aggregate (standard sand) were mixed for $30 \mathrm{~s}$ at low speed. Then activator was added and mixed medium speed. Lastly, the fresh mortars were filled into the plastic mould of $40 \mathrm{~mm} \times$

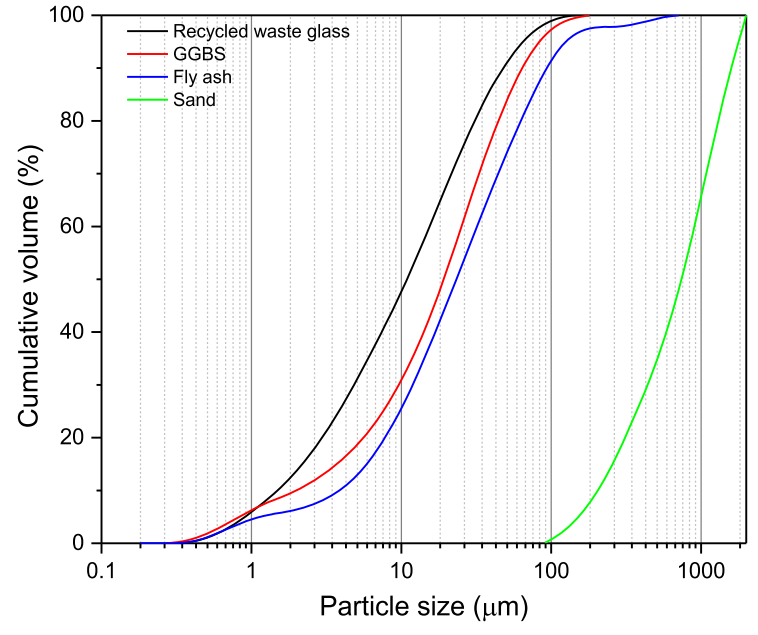

Fig. 2 Particle size distribution of materials employed as binder

$40 \mathrm{~mm} \times 160 \mathrm{~mm}$ and covered with plastic film for the first $24 \mathrm{~h}$ curing. After that, the mortar prisms were demoulded and covered by plastic film for ambient curing until further testing.

\subsubsection{Calorimetry test}

The calorimetry test was performed using an isothermal calorimeter (TAM Air, Thermometric). All measurements were conducted for $150 \mathrm{~h}$ under a constant temperature of $20^{\circ} \mathrm{C}$.

\subsubsection{Slump-flow and setting time}

The slump-flow of fresh mortars was conducted by the flow table test, according to EN 1015-3. An average value of two tested diameters were recorded by using a standard conical ring.

The initial and final setting time of various binders was measured according to the Vicat needle method as described in EN 196-3 [25].

\subsubsection{X-ray diffraction, $X R F$, particle size distribution, FTIR and specific density}

The X-ray diffraction test was conducted on pastes which were cured in ambient temperature for 28 days, using a Bruker D2 PHASER. After curing, all samples were crushed and immersed in isopropanol and dried at $40{ }^{\circ} \mathrm{C}$ in an oven for ceasing the reaction. Finally, all samples were crushed into powder by ball milling 
Table 2 Mix design for $1 \mathrm{~m}^{3}$

\begin{tabular}{llllllllll}
\hline Sample & GGBS $(\mathrm{kg})$ & Fly ash $(\mathrm{kg})$ & Recycled glass $(\mathrm{kg})$ & Sand $(\mathrm{kg})$ & Activator & $w / b$ & Flowabilty $(\mathrm{cm})$ & $\mathrm{Ca} / \mathrm{Si}$ & $\mathrm{Na} /(\mathrm{Si}+\mathrm{Al})$ \\
\hline $\mathrm{NH} 1$ & 251.5 & 251.5 & 0 & 1509.0 & $265.6^{\mathrm{a}}$ & 0.4 & 15.5 & 0.64 & 0.30 \\
$\mathrm{NH} 2$ & 252.4 & 151.4 & 100.9 & 1514.3 & $266.5^{\mathrm{a}}$ & 0.4 & 16.0 & 0.62 & 0.40 \\
$\mathrm{NH} 3$ & 150.0 & 250.0 & 100.0 & 1500.1 & $264.0^{\mathrm{a}}$ & 0.4 & 15.8 & 0.40 & 0.36 \\
$\mathrm{NH} 4$ & 200.9 & 200.9 & 100.5 & 1507.2 & $265.3^{\mathrm{a}}$ & 0.4 & 16.5 & 0.51 & 0.38 \\
$\mathrm{NC} 1$ & 251.5 & 251.5 & 0 & 1509.0 & $274.6^{\mathrm{b}}$ & 0.4 & 15.3 & 0.64 & 0.30 \\
$\mathrm{NC} 2$ & 252.4 & 151.4 & 100.9 & 1514.3 & $275.5^{\mathrm{b}}$ & 0.4 & 14.5 & 0.62 & 0.40 \\
$\mathrm{NC} 3$ & 150.0 & 250.0 & 100.0 & 1500.1 & $272.9^{\mathrm{b}}$ & 0.4 & 15.8 & 0.40 & 0.36 \\
$\mathrm{NC} 4$ & 200.9 & 200.9 & 100.5 & 1507.2 & $274.3^{\mathrm{b}}$ & 0.4 & 14.8 & 0.51 & 0.38 \\
\hline
\end{tabular}

${ }^{\mathrm{a}} \mathrm{NaOH}$ activator

${ }^{\mathrm{b}} \mathrm{NaOH}-\mathrm{Na}_{2} \mathrm{CO}_{3}$ activator

for XRD test. The parameters of the test were set as time $0.6 \mathrm{~s}$, increment 0.02 , scanning range from $10^{\circ}$ to $60^{\circ}, 30 \mathrm{kV}$ by Co tube.

The XRF test was conducted by using X-ray fluorescence spectrometer (PANalytical Epsilon 3). Pressed powder samples were prepared and analyzed using the Omnian method.

The particle size distributions of raw materials were tested by the laser granulometry (Master sizer 2000).

The Fourier transform infrared spectroscopy (FTIR) measurement was performed in a Varian 3100 instrument with the wavenumbers ranging from 4000 to $400 \mathrm{~cm}^{-1}$ with a resolution of $1 \mathrm{~cm}^{-1}$.

The specific density of materials was measured using a Micromeritics Accupyc II 1340 Pycnometer.

\subsubsection{Mechanical performance}

The strength tests were carried out according to EN 196-1 [26]. Prism samples with a size of $40 \mathrm{~mm} \times$ $40 \mathrm{~mm} \times 160 \mathrm{~mm}$ were prepared and tested after 7 days and 28 days of curing. An average value of flexural strength was calculated by testing 3 prism samples. After that, a compressive strength test was conducted on 6 specimens.

\subsubsection{Drying shrinkage}

The drying shrinkage tests were conducted using prisms of $40 \mathrm{~mm} \times 40 \mathrm{~mm} \times 160 \mathrm{~mm}$. After $24 \mathrm{~h}$ sealed curing, the specimens were moved to an environment with $50 \% \mathrm{RH}$ and a temperature of
$20{ }^{\circ} \mathrm{C}$. Then the length and mass of different mortar samples were measured and recorded until 90 days.

\subsubsection{Carbonation test}

Carbonation curing was conducted by a carbonation chamber. The relative humidity was set as $65 \%$ (in the range of optimal value for carbonation test from previous studies [27]), the temperature was set at $25{ }^{\circ} \mathrm{C}$, and the $\mathrm{CO}_{2}$ gas dosage keeps a constant of $20 \%$ at ambient pressure. Samples were moved to the carbonation chamber for the test after 28 days normal curing. The phenolphthalein solution was sprayed on the fracture surface of samples after different ages to test the uncarbonated area. Then the percentages of the uncarbonated area were identified and calculated by using Image $\mathrm{J}$.

\section{Results}

3.1 Reaction kinetics and products characterization

\subsubsection{Isothermal calorimetry test}

Isothermal calorimetry tests were conducted for the different mixtures activated by $\mathrm{NaOH}$ type and $\mathrm{NaOH} /$ $\mathrm{Na}_{2} \mathrm{CO}_{3}$ type activator. As shown in Fig. 3, all mixtures exhibit a typical four-stage heat evolution curve of initial dissolution, induction, acceleration to deceleration and stable period [28-30]. It can be identified that different mixtures show a variation of 


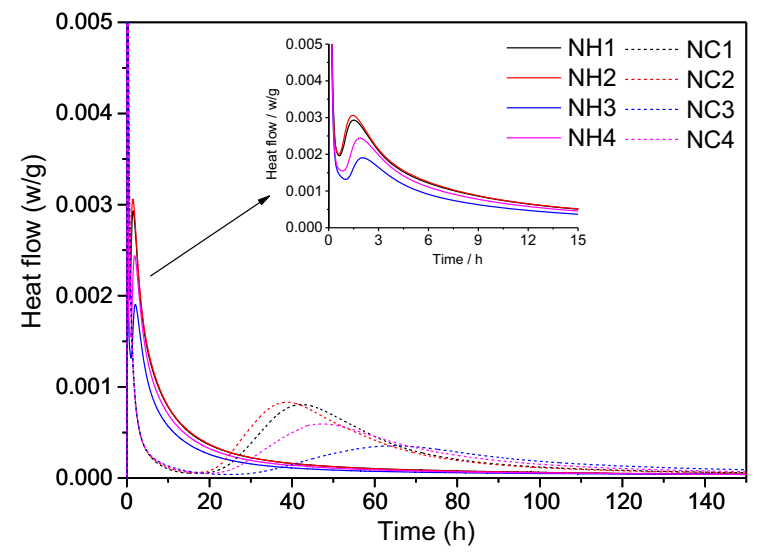

Fig. 3 Reaction heat development of various binders

peak intensity and acceleration/deceleration period. The different parts of slag-fly ash binder replaced by waste glass induce the enhancement or reduction of the reaction intensity and reaction rate. For $\mathrm{NaOH}$ activated mixtures, NH2 shows the highest peak intensity and shortest induction period compared to the reference (NH1). NH3 and NH4 exhibit a significant lower heat peak intensity and a longer induction period. Binders activated by $\mathrm{NaOH} / \mathrm{Na}_{2} \mathrm{CO}_{3}$ blended activator exhibit a relatively longer induction period and lower reaction intensity compared to $\mathrm{NaOH}$ series samples. However, the similar influence of waste glass incorporation on the reaction kinetics of slag/fly ash system are observed. NC2 (glass replacing fly ash part) shows the shortest induction period and highest reaction intensity compared to other blended activator activated binders, while NC3 (glass replacing slag part) exhibits the slowest reaction rate.

For all $\mathrm{NaOH}$ and $\mathrm{NaOH} / \mathrm{Na}_{2} \mathrm{CO}_{3}$ series samples, the highest reaction intensity and reaction rate is observed in $\mathrm{NH} 2$ and $\mathrm{NC} 2$, respectively, which is related to mixtures containing $50 \%$ of GGBS, $30 \%$ of fly ash and $20 \%$ of waste glass powder. On the contrary, the binder exhibiting the lowest reactivity is found in $\mathrm{NH} 3$ and $\mathrm{NC} 3$, mixtures containing 30\% of GGBS, $50 \%$ of fly ash and $20 \%$ waste glass. These results indicate that the waste glass powder may show a lower reactivity than GGBS, while higher reactivity than fly ash when activated by $\mathrm{NaOH}$ or $\mathrm{NaOH} /$ $\mathrm{Na}_{2} \mathrm{CO}_{3}$ type activator.

This difference of heat flow is induced by the significant higher $\mathrm{pH}$ provided by the $\mathrm{NaOH}$, which accelerates the dissolution of $\mathrm{Al}$ and $\mathrm{Si}$ during the induction period [31]. As a consequence, as higher reaction rate and reaction intensity can be observed in the first hours as shown in Fig. 3. On the contrary, the $\mathrm{Na}_{2} \mathrm{CO}_{3}$ shows a limitation on providing a high $\mathrm{pH}$ environment in the first hours. This is also the reason why $\mathrm{NaOH} / \mathrm{Na}_{2} \mathrm{CO}_{3}$ activated samples show a relatively long duration to reach the setting compared to $\mathrm{NaOH}$ activated specimens. In some cases, the reaction heat flow peak of $\mathrm{Na}_{2} \mathrm{CO}_{3}$ activated slag binder was presented after $50-60 \mathrm{~h}$ of reaction $[32,33]$. In the present study, the heat flow peaks of binders activated by $\mathrm{NaOH} / \mathrm{Na}_{2} \mathrm{CO}_{3}$ locate in the range of from 35 to $60 \mathrm{~h}$, which is faster compared to previous studies. This is induced by combining $\mathrm{NaOH}$ and $\mathrm{Na}_{2} \mathrm{CO}_{3}$ as activator.

\subsubsection{XRD and FTIR analysis}

The XRD patterns of the paste samples are shown in Fig. 4. As can be seen, some minerals are found in all mixtures, regardless of the activator types. For example, quartz (PDF 01-089-1961) and mullite (PDF 01-083-1881), which are the residual minerals in fly ash. In comparison to the XRD data of raw materials (shown in Fig. 1), many new peaks were formed after 28 days reaction by the activation of $\mathrm{NaOH}$ or $\mathrm{NaOH}-$ $\mathrm{Na}_{2} \mathrm{CO}_{3}$. In $\mathrm{NaOH}$ activated samples, a peak with broad hump and low intensity can be identified between $33^{\circ}$ and $35^{\circ}$, which is related to the formation of C-S-H with a low degree of crystallinity [34-36]. In addition, hydrotalcite (PDF 00-014-0191), garronite (PDF 01-085-1569) and cancrinite (PDF 00-015-0734) also can be found in all samples as the usual products in similar binder systems [37, 38]. For the samples activated by $\mathrm{NaOH}-\mathrm{Na}_{2} \mathrm{CO}_{3}$, a different phase-gaylussite (PDF 00-021-0343) was formed. The addition of waste glass in binders shows no significant effect on the variation of reaction products. It is interesting to notice that the peaks of cancrinite in $\mathrm{NaOH}$ activated binders are relatively weak after the incorporation of waste glass. This may be induced by the variation of the $\mathrm{SiO}_{2} / \mathrm{Al}_{2} \mathrm{O}_{3}$ ratio after the addition of waste glass.

To further study the reaction products of different mixtures, FTIR was employed as shown in Fig. 5. The location of the dash line is determined by the peak of $\mathrm{Si}-\mathrm{O}-\mathrm{T}$ in reference samples, which contain $50 \%$ slag and $50 \%$ fly ash as a binder (shown as $\mathrm{NH} 1$ and $\mathrm{NC} 1$, repectively). For all alkali activated samples, the main 


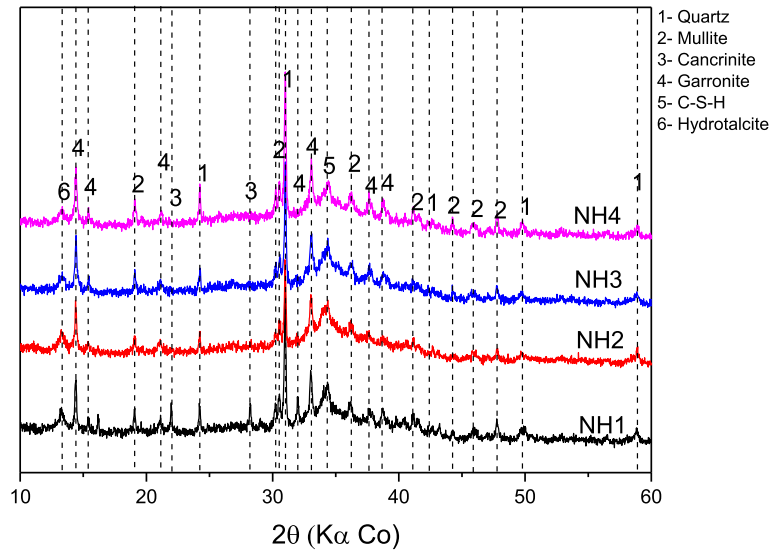

(a)

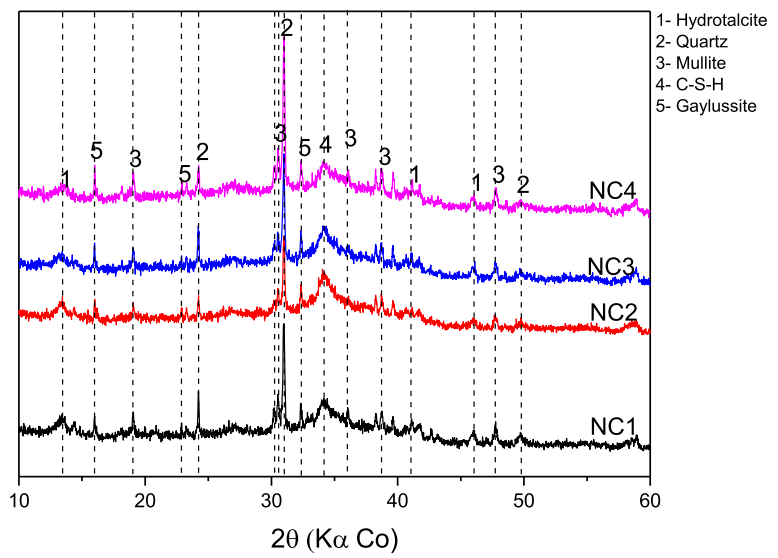

(b)

Fig. 4 XRD patterns of different mixtures $\mathbf{a} \mathrm{NaOH}$ activated binders and $\mathbf{b} \mathrm{NaOH}-\mathrm{Na}_{2} \mathrm{CO}_{3}$ activated binders

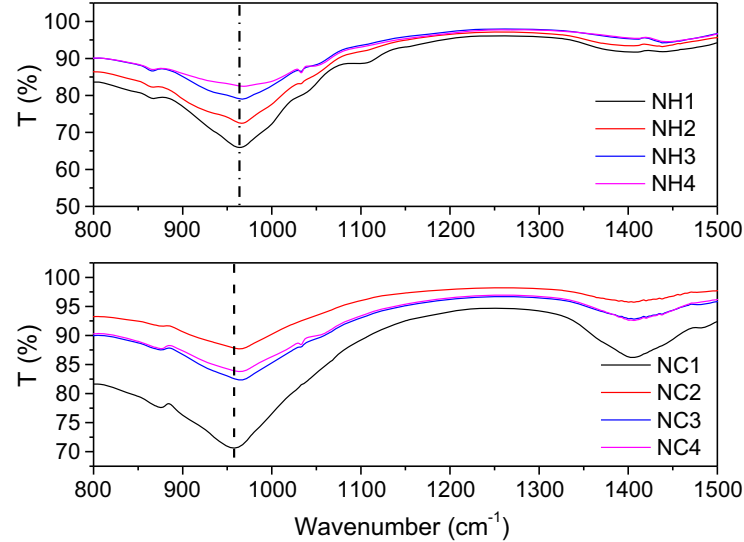

Fig. 5 FITR of different mixtures after 28 days curing

peaks shown in the present range are around $870 \mathrm{~cm}^{-1}, 960 \mathrm{~cm}^{-1}$, and $1406 \mathrm{~cm}^{-1}$. The peaks located around $870 \mathrm{~cm}^{-1}$ and $1406 \mathrm{~cm}^{-1}$ are induced by the existence of the $\mathrm{C}-\mathrm{O}$ bond [39], which appearances as carbonate in samples. It can be hydrotalcite, which has been identified in the XRD patterns. The appearance of carbonate in $\mathrm{NaOH}$ activated samples might be induced by the carbonation during the sample preparation, while for the $\mathrm{NaOH}-$ $\mathrm{Na}_{2} \mathrm{CO}_{3}$ activated specimens, it is resulted by the formation of gaylussite $\left(\mathrm{Na}_{2} \mathrm{Ca}\left(\mathrm{CO}_{3}\right)_{2} \cdot 5 \mathrm{H}_{2} \mathrm{O}\right)$, which also has been found with XRD. As it can be seen, the sodium hydroxide activated slag-fly ash binder system shows main peak around $964 \mathrm{~cm}^{-1}$, and at $957 \mathrm{~cm}^{-1}$ in sodium hydroxide-sodium carbonate activated slag-fly ash. This band is related to the $v_{3}$ vibration of $\mathrm{Si}-\mathrm{O}-\mathrm{T}$ bond, which generally exists in $\mathrm{N}-\mathrm{A}-\mathrm{S}-\mathrm{H}$ and $\mathrm{C}-\mathrm{A}-\mathrm{S}-\mathrm{H}$ gel in alkali activated slag-fly ash systems [15]. After $20 \%$ of waste glass powder was introduced in the slag-fly ash binder, the $\mathrm{Si}-\mathrm{O}-\mathrm{T}$ peaks in all waste glass mixtures exhibits a shift to higher wavenumbers. The addition of waste glass powder introduced an additional $\mathrm{Si}$ source to the reaction system; as a consequence, more $\mathrm{Si}$ could be incorporated into the gel network to form a $\mathrm{Si}$ rich structure [40], which can generate a higher polymerziation degree of reaction products.

\subsection{Setting and mechanical behaviours}

\subsubsection{Setting time}

The setting behaviour of various binder systems is shown in Table 3. As it can be seen, the significant differences are observed between different binders, as well as between samples with different activators. For $\mathrm{NaOH}$ activated binders, the reference sample, NH1, reaches the initial setting at $89 \mathrm{~min}$, while the final setting at $139 \mathrm{~min}$. Comparing to $\mathrm{NH} 1, \mathrm{NH} 2$ shows a slightly shorter initial and final setting time of $85 \mathrm{~min}$ and $129 \mathrm{~min}$, respectively. On the contrary, NH3 experiences a longer duration to reach the initial and final setting, of $116 \mathrm{~min}$ and $163 \mathrm{~min}$, respectively. For $\mathrm{NaOH}-\mathrm{Na}_{2} \mathrm{CO}_{3}$ activated binders, all samples show a relatively longer duration for the setting than $\mathrm{NaOH}$ activated samples. $\mathrm{NC} 2$ and $\mathrm{NC} 4$ exhibit almost the same duration to the setting, which is shorter than the reference NC1. The longest setting time is shown by NC3. This observation is in 
Table 3 Setting and mechanical performance of mortars

\begin{tabular}{|c|c|c|c|c|c|c|}
\hline \multirow[t]{2}{*}{ Sample ID } & \multirow[t]{2}{*}{ Initial setting $(\min )$} & \multirow[t]{2}{*}{ Final setting (min) } & \multicolumn{2}{|c|}{ Flexural strength $(\mathrm{MPa})$} & \multicolumn{2}{|c|}{ Compressive strength (MPa) } \\
\hline & & & 7 days & 28 days & 7 days & 28 days \\
\hline NH1 & 89 & 139 & $2.67 \pm 0.07$ & $4.21 \pm 0.04$ & $8.34 \pm 0.11$ & $12.77 \pm 0.36$ \\
\hline $\mathrm{NH} 2$ & 85 & 129 & $3.03 \pm 0.07$ & $4.11 \pm 0.01$ & $8.34 \pm 0.10$ & $10.82 \pm 0.18$ \\
\hline NH3 & 156 & 206 & $1.52 \pm 0.03$ & $2.89 \pm 0.05$ & $4.16 \pm 0.09$ & $9.73 \pm 0.25$ \\
\hline NH4 & 116 & 163 & $2.16 \pm 0.04$ & $3.38 \pm 0.18$ & $6.16 \pm 0.12$ & $9.78 \pm 0.28$ \\
\hline $\mathrm{NC} 1$ & 320 & 410 & $5.20 \pm 0.08$ & $6.29 \pm 0.09$ & $16.38 \pm 1.16$ & $25.68 \pm 0.17$ \\
\hline $\mathrm{NC} 2$ & 306 & 380 & $4.84 \pm 0.11$ & $5.30 \pm 0.22$ & $16.09 \pm 0.76$ & $23.89 \pm 0.30$ \\
\hline NC3 & 370 & 470 & $3.23 \pm 0.06$ & $5.12 \pm 0.24$ & $12.38 \pm 0.23$ & $17.99 \pm 0.64$ \\
\hline $\mathrm{NC} 4$ & 307 & 379 & $4.18 \pm 0.01$ & $5.13 \pm 0.05$ & $14.00 \pm 0.22$ & $21.62 \pm 0.85$ \\
\hline
\end{tabular}

accordance with the results of the calorimetry test in Sect. 3.1.1.

\subsubsection{Mechanical performance}

The mechanical performances of different alkali activated mortars are shown in Table 3. The incorporation of waste glass in binders reduces the strength performance of mortars activated by $\mathrm{NaOH}$ or $\mathrm{NaOH}-$ $\mathrm{Na}_{2} \mathrm{CO}_{3}$ after 28 days. For $\mathrm{NaOH}$ activated mortars, fly ash-slag samples (NH1) exhibit an overage compressive strength of $12.76 \mathrm{MPa}$. After the waste glass was used to replace the fly ash part, slag part or all binder, the compressive strength of 28 days are 10.82 $\mathrm{MPa}$, 9.73 $\mathrm{MPa}$, and $9.78 \mathrm{MPa}$, respectively. The reduction of mechanical performance is mostly induced by the decreasing of the slag proportion, for example, NH3 (30\% slag) exhibits the lowest strength performance.

The obvious higher strength performance can be found in $\mathrm{NaOH}-\mathrm{Na}_{2} \mathrm{CO}_{3}$ activated mortars. The reference sample (NC1) achieves a compressive strength of $25.68 \mathrm{MPa}$, while $23.89 \mathrm{MPa}$, $17.98 \mathrm{MPa}$ and $21.62 \mathrm{MPa}$ for waste glass containing samples $\mathrm{NC} 2, \mathrm{NC} 3$ and $\mathrm{NC} 4$, respectively. The addition of waste glass in $\mathrm{NaOH}-\mathrm{Na}_{2} \mathrm{CO}_{3}$ activated mortars shows a similar effect on the strength development as $\mathrm{NaOH}$ activated mortars. The slag component is a critical parameter of strength behaviour for alkali activated slag based materials [41]. The difference in mechanical performance is possibly induced by the chemical composition of binders, which will be discussed in the following part.
The compressive strength of $\mathrm{NaOH} / \mathrm{Na}_{2} \mathrm{CO}_{3}$ activated mortars are obviously higher than the mortars activated by $\mathrm{NaOH}$ at 7 days and 28 days only. As it is well known, the mechanical performance of alkali activated concrete is influenced by the type and the concentration of activator [42]. In the previous research, $\mathrm{NaOH}$ activator helped to form $\mathrm{C}-\mathrm{S}-\mathrm{H}$ containing high $Q^{2}$ value of $\mathrm{Si}$, while no $Q^{3}$ value was found, this kind of long chains indicate a low strength performance of samples. However, the application of $\mathrm{Na}_{2} \mathrm{CO}_{3}$ induced more $Q^{3}$ value of $\mathrm{Si}$ and very low $Q^{2}$, which indicates a cross-linked structure of $\mathrm{C}-\mathrm{S}-\mathrm{H}$ [43]. As a consequence, the mechanical performance will be higher. In addition, the existence of long chains in $\mathrm{NaOH}$ activated samples was also identified by the FTIR results in Fig. 5 that $\mathrm{NaOH}$ activated slag-fly ash binders shows a higher wavenumber of $\mathrm{Si}-\mathrm{O}-\mathrm{T}$ than $\mathrm{NaOH} / \mathrm{Na}_{2} \mathrm{CO}_{3}$ activated samples.

\subsection{Shrinkage and carbonation resistance performance evaluation}

\subsubsection{Drying shrinkage}

The length deformation and mass change during the drying shrinkage test (90 days) are shown in Figs. 6 and 7. The addition of waste glass in slag-fly ash binders both increases the final drying shrinkage of both $\mathrm{NaOH}$ and $\mathrm{Na}_{2} \mathrm{CO}_{3}-\mathrm{NaOH}$ activated mortars. For $\mathrm{NaOH}$ activated binders, the highest drying shrinkage is observed in NH3, which contains $30 \%$ slag, $20 \%$ waste glass, and $50 \%$ fly ash. At the same time, sample NH1 (50\% slag and 50\% fly ash) exhibits 


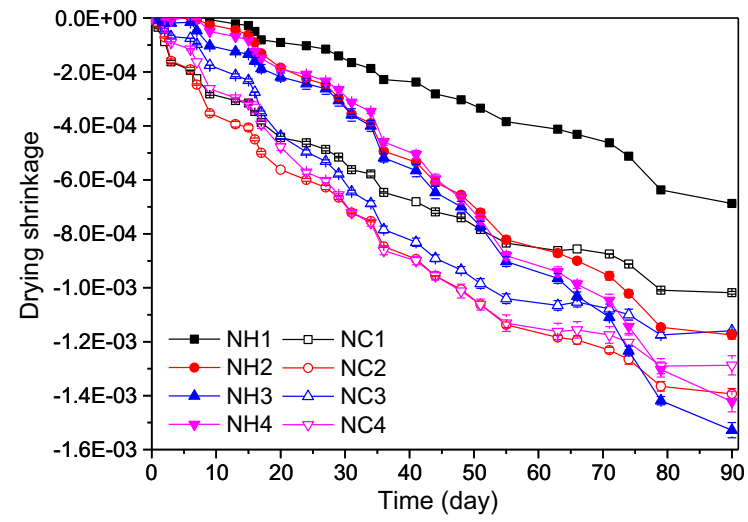

Fig. 6 Drying shrinkage of different mortars

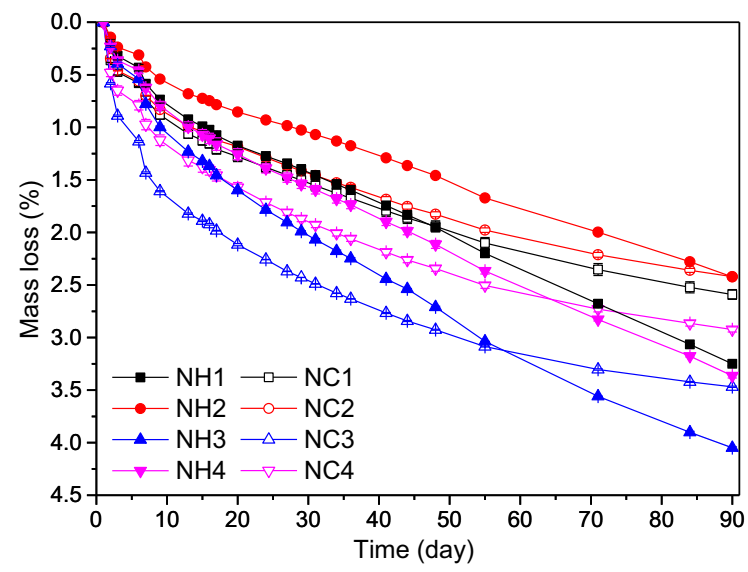

Fig. 7 Mass loss during shrinkage test

a significantly lower drying shrinkage compared to other samples. On the contrary, when blended activator was used, NC2 (50\% slag, 30\% fly ash and $20 \%$ waste glass) presents the highest drying shrinkage during the test. In addition, as the fly ash proportion increases, the drying shrinkage of mortars keeps decreasing, which agrees with the previous study [14].

The mass change of all mixtures was recorded during the shrinkage test and is shown in Fig. 7. It is noticeable that the results of mass change can not totally agree with the drying shrinkage data. For sodium hydroxide activated samples, NH3 presents the highest mass loss, while NH2 exhibits the lowest mass loss. A similar trend also can be found in sodium hydroxide-sodium carbonate activated mortars of the same dry mixtures design. Furthermore, mortars activated by sodium hydroxide present an overall higher mass loss compared to the sample activated by sodium hydroxide-sodium carbonate. These indicate that samples activated by blended activators have less content of evaporable water than samples activated by $\mathrm{NaOH}$.

\subsubsection{Resistance to carbonation}

The uncarbonated area of mortars by different duration of $\mathrm{CO}_{2}$ penetration is shown in Fig. 8. As it can be seen, the application of waste glass as part of the binder in slag-fly ash binders induces the difference of the resistance to carbonation for both for $\mathrm{NaOH}$ and $\mathrm{NaOH}-\mathrm{Na}_{2} \mathrm{CO}_{3}$ series. $\mathrm{NH} 1$ shows an uncarbonated area of $94.8 \%$ after 3 days carbonation; this value is reduced to $70.0 \%$ after 8 weeks. When the waste glass was added as part of binders, NH2 (replacing fly ash), $\mathrm{NH} 3$ (replacing slag), and NH4 (replacing all binder) exhibit the uncarbonated area of 95.9\%, 94.7\% and $91.9 \%$, respectively after 3 days carbonation. After 8 weeks carbonation, they present the uncarbonated area of $78.8 \%, 73.0 \%$, and $73.6 \%$, respectively. This indicates that the addition of waste glass as part of binders improved the resistance to carbonation of sodium hydroxide activated binder systems.

In the comparison to $\mathrm{NaOH}$ activated series samples, blended activator- $\mathrm{NaOH}-\mathrm{Na}_{2} \mathrm{CO}_{3}$-activated samples all exhibit a poor performance of resistance to carbonation. Even though, the incorporation of waste glass still contributes to an enhancement of the resistance to carbonation. The uncarbonated area of slag-fly ash mortar (NC1) only accounts for 59.3\% after 3 days carbonation curing, and $11.4 \%$ for

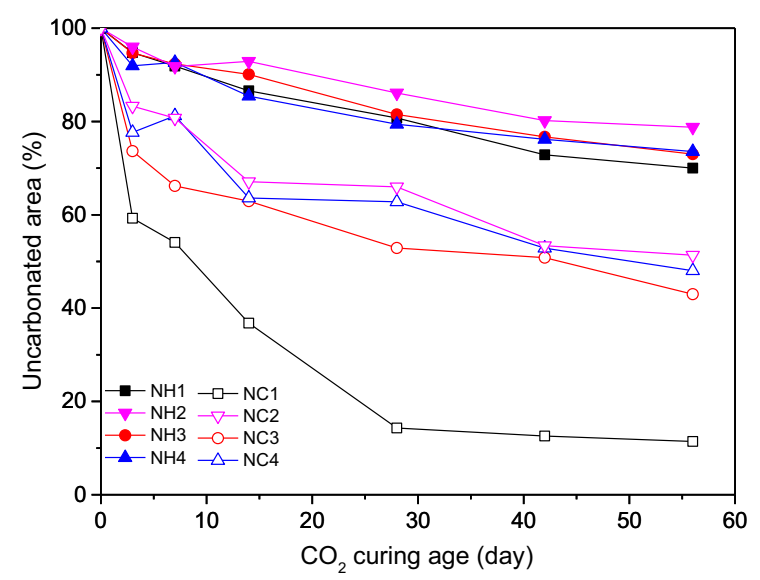

Fig. 8 Uncarbonated area of samples subjected to various duration of $\mathrm{CO}_{2}$ penetration 
8 weeks carbonation. After the waste glass added as part of binders, uncarbonated area after 3 days are $83.3 \%, 73.6 \%$, and $77.6 \%$ for $\mathrm{NC} 2, \mathrm{NC} 3$ and $\mathrm{NC} 4$, respectively. The incorporation of waste glass enhances the resistance for carbonation significantly at an early age. Furthermore, this enhancement also can be observed at a late age, for example, 8 weeks. The residual uncarbonated area of NC2 is $51.4 \%$, while $43.0 \%$ and $48.0 \%$ for $\mathrm{NC} 3$ and $\mathrm{NC} 4$; almost four times the uncarbonated area in waste glass blended binders compared to $11.4 \%$ of the slag-fly ash binder (NC1) activated by sodium hydroxide-sodium carbonate.

It is interesting to notice that $\mathrm{NaOH}$ activated mortars show a significant better resistance to carbonation compared to samples activated by $\mathrm{NaOH} /$ $\mathrm{Na}_{2} \mathrm{CO}_{3}$ during all 8 weeks of carbonation. However, the $\mathrm{NaOH}$ series samples exhibit higher mass loss during shrinkage test and a lower strength, which indicates a more porous microstructure and less hydration products. Generally, these kinds of samples are believed to have a poor resistance to $\mathrm{CO}_{2}$ penetration for ordinary concrete [44]. Nevertheless, the $\mathrm{NaOH}$ series mortars still keep more than $70 \%$ uncarbonated area after 8 weeks $\mathrm{CO}_{2}$ penetration as shown in Fig. 8, while less than $20 \%$ for $\mathrm{NaOH} /$ $\mathrm{Na}_{2} \mathrm{CO}_{3}$ slag-fly ash mortar is uncarbonated. This can be explained by several factors. At first, the $\mathrm{NaOH}$ type activator shows obviously higher $\mathrm{pH}$ than the blended activator, which can provide a high buffer capacity to resistance the reduction of $\mathrm{pH}$ induced by $\mathrm{CO}_{2}$ dissolving in the pore solution. It is believed that the decalcification of $\mathrm{C}-\mathrm{S}-\mathrm{H}$ only be observed at low $\mathrm{pH}$ [45]. Secondly, hydrotaclite-like minerals as the main reaction products in alkali activated slag, it has a layered double hydroxide structure. Generally, the interlayer can incorporate $\mathrm{OH}^{-}, \mathrm{NO}_{3}{ }^{-}, \mathrm{Cl}^{-}$and $\mathrm{CO}_{3}{ }^{2-}$ [46]. In some cases, these anions can be replaced by other one, which can provide a capacity for hazardous ions storage [47]. For $\mathrm{NaOH}$ activated binders, $\mathrm{OH}^{-}$can be the mainly anions in this structure, and it is possible that $\mathrm{OH}^{-}$can be replaced by $\mathrm{CO}_{3}{ }^{2-}$ from $\mathrm{CO}_{2}$ dissolving. During this process, additional $\mathrm{OH}^{-}$will be released as the $\mathrm{pH}$ buffer. Where as in $\mathrm{NaOH}-\mathrm{Na}_{2} \mathrm{CO}_{3}$ activated binders, $\mathrm{OH}^{-}$ has been partially replaced by the $\mathrm{CO}_{3}{ }^{2-}$ from $\mathrm{Na}_{2} \mathrm{CO}_{3}$, which results in the limitation of buffer capacity. As a consequence, $\mathrm{NaOH}$ activated mortars shows better ability of carbonation resistance.

\subsection{Discussion}

\subsubsection{The influence of waste glass addition on reaction kinetics and mechanical performance}

As detailed above, $\mathrm{NaOH} / \mathrm{Na}_{2} \mathrm{CO}_{3}$ contributes to the higher mechanical performance at the same ages, but lower the resistance for the carbonation compared to $\mathrm{NaOH}$ activator. The incorporation of waste glass powder as part of the binders induces significant differences of performances, such as reaction kinetics and products. In the present study, waste glass was used as a replacement of slag, fly ash or total binder. From the XRF data as shown in Table 1, high dosage of $\mathrm{Na}_{2} \mathrm{O}$ can be identified. When the waste glass was used to replace $20 \%$ fly ash in slag-fly ash binder, a higher reaction intensity and shorter induction period were presented. In the previous study, fly ash was identified to show a much slow dissolution rate at ambient temperature, which is caused by a high polymerization extent of $\mathrm{Si}$ and $\mathrm{Al}$ in the amorphous phase [48]. In the results of the heat flow peak in present study, the higher reaction rate corresponds to the additional $\mathrm{Si}$ and $\mathrm{Na}$ dissolution by replacing fly ash by waste glass compared to reference sample. However, when waste glass replaces $20 \%$ of slag or $20 \%$ total binder, the induction period was prolonged, as well as the reaction intensity. This can be explained by the reduced $\mathrm{Ca}$ in binders. In slag-fly ash binder systems, higher slag proportion usually induced high reaction intensity and cumulative reaction heat, as well as a reduction of setting time [49]. Subsequently, the strength performance of mortars in this study is associated to the slag proportion neglecting the activator type. In other words, a higher $\mathrm{Ca} / \mathrm{Si}$ ratio results in the higher mechanical performance of slagfly ash-waste glass binder system. A slightly lower strength of the waste glass replacing fly ash samples was exhibited at 28 days, which may be caused by the reduction of the formation of $\mathrm{C}-\mathrm{A}-\mathrm{S}-\mathrm{H}$ at late age compared to slag-fly ash binder. In addition, the higher $\mathrm{Si} / \mathrm{Al}$ ratio after the waste glass incorporation may induce the weak peaks of cancrinite (a reaction product in $\mathrm{NaOH}$ activated slag/fly ash system [50]). 


\subsubsection{The influence of waste glass addition on the carbonation resistance}

The additional $\mathrm{Si}$ in the pore solution also can induce changes of microstructure and capillary tension of pore solution. A small pore size and higher capillary force was identified when using additional Si source in binder systems in a previous study [12], which contributes to a high shrinkage. This agrees with the observation of drying shrinkage and mass loss in this study. Generally, drying shrinkage contains shrinkage caused by water evaporation and polymerization of reaction. It is interesting to notice that $\mathrm{NaOH}$ activated slag/fly ash mortar exhibits the lowest drying shrinkage, which is expected to have the lowest mass loss. However, the lowest mass loss is presented in slag/(fly ash + waste glass) mortar. At the same time, waste glass replacing slag and total binder mortars exhibit a similar trend of drying shrinkage as the total mass loss. This indicates that, when the waste glass was used as fly ash replacement, the shrinkage caused by chemical reaction is large than the shrinkage induced by water evaporation. However, for other samples, water evaporation dominates the drying shrinkage. When $\mathrm{NaOH} /$ $\mathrm{Na}_{2} \mathrm{CO}_{3}$ was used as activator, the glass replacing fly ash mortar shows the largest drying shrinkage and the lowest mass loss during the test. This proves that the glass as fly ash replacement contributes to a higher shrinkage in $\mathrm{NaOH} / \mathrm{Na}_{2} \mathrm{CO}_{3}$ than in $\mathrm{NaOH}$ activated mortars. The higher dissolution rate of glass powder in $\mathrm{NaOH} / \mathrm{Na}_{2} \mathrm{CO}_{3}$ solution than in $\mathrm{NaOH}$ solution corresponds to the higher reaction degree [51], as a consequence, the shrinkage induced by chemical reaction is higher.

The incorporation of waste glass in slag-fly ash binders shows a positive effect on the ability of resistance for carbonation as shown in Fig. 8. The waste glass in binders contributes to a higher carbonation resistance. To investigate the correlation between materials composition and the carbonation resistance, the $\mathrm{Na} /(\mathrm{Si}+\mathrm{Al})$ ratio was calculated and showed in Fig. 9. It can be seen that there is a linear relationship between the $\mathrm{Na} /(\mathrm{Si}+\mathrm{Al})$ ratio and the uncarbonated area. $\mathrm{NaOH}$ and $\mathrm{NaOH} / \mathrm{Na}_{2} \mathrm{CO}_{3}$ activators were designed to contribute the same $\mathrm{Na}_{2} \mathrm{O} \%$ to binders in this study, but the incorporation of waste glass in binders also brings an additional Na source to the system. By incorporating soda-lime glass, the releasing alkali still can provide or keep a high pore

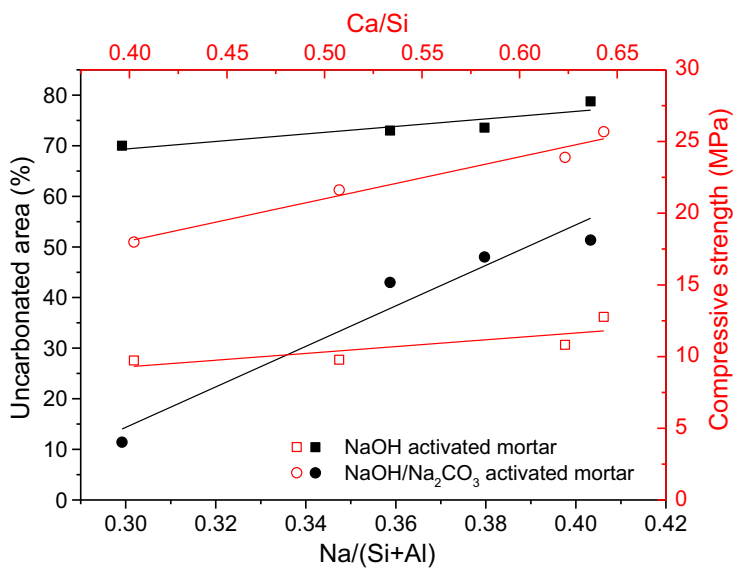

Fig. 9 The correlation between $\mathrm{Na} /(\mathrm{Si}+\mathrm{Al})$ and uncarbonated area and between $\mathrm{Ca} / \mathrm{Si}$ and compressive strength

solution alkalinity. This observation agrees with the study of Shi, which presented that the increasing alkali dosage and silicate modulus both result in a high carbonation resistance [24]. On the other hand, a small average pore size was observed by applying the additional Si source [12], which can also provide a positive effect on the resistance to $\mathrm{CO}_{2}$ penetration. Furthermore, in some studies, waste glass was seen as a sodium silicate based material, that can be used to produce activator in alkali activated concrete [20, 22], and it was identified to show a similar activation mechanism as water glass [22]. It has been observed that water glass activated concrete shows a better performance of carbonation resistance compared to $\mathrm{NaOH}$ and $\mathrm{Na}_{2} \mathrm{CO}_{3}$ activators [52]. In general, the incorporation of waste glass in alkali activated slagfly ash binders provides an enhancement of carbonation resistance. Nevertheless, a lower mechanical performance caused by the replacement part was observed in the case of the lower $\mathrm{Ca} / \mathrm{Si}$ ratio in the binder composition.

\section{Conclusions}

This investigation illustrates the reaction mechanism, mechanical performance and durability properties of the application waste glass as the binder in slag-fly ash alkali activated mortars. Different alkali activator types were used to evaluate the performance of mortars. The reaction kinetics, reaction products, strength performance, drying shrinkage and resistance 
for carbonation were tested. The following conclusions can be drawn:

1. Applying waste glass as a $20 \%$ replacement of fly ash in ternary binders induces a slightly higher reactivity and shorter induction period compared to the slag-fly ash binders. As a consequence, a shorter setting time can be observed. A longer setting period and lower reactivity can be found when the waste glass was used to replace $20 \%$ of slag in binders.

2. There is no obvious difference in reaction products between waste glass containing samples and slag-fly ash samples. However, the FTIR results indicate that the polymerization degree of $\mathrm{C}-\mathrm{S}-\mathrm{H}$ was improved after the waste glass was added.

3. The waste glass addition in the slag-fly ash binders changed the $\mathrm{Ca} / \mathrm{Si}$ of dry mixtures, as a consequence, an increase of compressive strength followed the increase of $\mathrm{Ca} / \mathrm{Si}$ ratio.

4. Using the waste glass to replace $20 \%$ of slag results in the largest drying shrinkage and mass loss of samples activated by $\mathrm{NaOH}$. By activation of $\mathrm{NaOH}-\mathrm{Na}_{2} \mathrm{CO}_{3}$, applying waste glass to replace $20 \%$ of fly ash induces the largest drying shrinkage. Overall, both samples containing waste glass contribute to higher drying shrinkage.

5. The application of $20 \%$ of waste glass in binders induces an improvement of carbonation resistance, especially for samples activated by $\mathrm{NaOH}-$ $\mathrm{Na}_{2} \mathrm{CO}_{3}$. The resistance to carbonation can be improved by $316 \%$ on average after the incorporation of waste glass in slag-fly ash binders activated by $\mathrm{NaOH}-\mathrm{Na}_{2} \mathrm{CO}_{3}$.

Acknowledgements This research was supported by the funding of China Scholarship Council (No. 201606300062) and Eindhoven University of Technology.Compliance with ethical standards

\section{Compliance with ethical standards}

Conflict of interest The authors declare that they have no conflict of interest.

Open Access This article is distributed under the terms of the Creative Commons Attribution 4.0 International License (http:// creativecommons.org/licenses/by/4.0/), which permits unrestricted use, distribution, and reproduction in any medium, provided you give appropriate credit to the original author(s) and the source, provide a link to the Creative Commons license, and indicate if changes were made.

\section{References}

1. Feiz R, Ammenberg J, Eklund M, Helgstrand A, Marshall R (2015) Improving the $\mathrm{CO}_{2}$ performance of cement, part I: utilizing life-cycle assessment and key performance indicators to assess development within the cement industry. J Clean Prod 98:272-281

2. Yang K-H, Jung Y-B, Cho M-S, Tae S-H (2015) Effect of supplementary cementitious materials on reduction of $\mathrm{CO}_{2}$ emissions from concrete. J Clean Prod 103:774-783

3. Torres-Carrasco M, Puertas F (2015) Waste glass in the geopolymer preparation. Mechanical and microstructural characterisation. J Clean Prod 90:397-408

4. Crossin E (2015) The greenhouse gas implications of using ground granulated blast furnace slag as a cement substitute. J Clean Prod 95:101-108

5. Liu G, Florea MVA, Brouwers HJH (2019) Performance evaluation of sustainable high strength mortars incorporating high volume waste glass as binder. Constr Build Mater 202:574-588

6. Liu G, Florea MVA, Brouwers HJH (2018) The hydration and microstructure characteristics of cement pastes with high volume organic-contaminated waste glass powder. Constr Build Mater 187:1177-1189

7. Zeng Q, Li K, Fen-chong T, Dangla P (2012) Pore structure characterization of cement pastes blended with high-volume fly-ash. Cem Concr Res 42(1):194-204

8. Kayali O, Sharfuddin Ahmed M (2013) Assessment of high volume replacement fly ash concrete-concept of performance index. Constr Build Mater 39:71-76

9. Brough A, Atkinson A (2002) Sodium silicate-based, alkaliactivated slag mortars: part I. Strength, hydration and microstructure. Cem Concr Res 32(6):865-879

10. Jeon D, Jun Y, Jeong Y, Oh JE (2015) Microstructural and strength improvements through the use of $\mathrm{Na}_{2} \mathrm{CO}_{3}$ in a cementless $\mathrm{Ca}(\mathrm{OH})_{2}$-activated Class $\mathrm{F}$ fly ash system. Cem Concr Res 67:215-225

11. Škvára F, Kopecký L, Šmilauer V, Bittnar Z (2009) Material and structural characterization of alkali activated low-calcium brown coal fly ash. J Hazard Mater 168(2-3):711-720

12. Ye H, Cartwright C, Rajabipour F, Radlińska A (2017) Understanding the drying shrinkage performance of alkaliactivated slag mortars. Cem Concr Compos 76:13-24

13. Ma Y, Ye G (2015) The shrinkage of alkali activated fly ash. Cem Concr Res 68:75-82

14. Lee NK, Jang JG, Lee HK (2014) Shrinkage characteristics of alkali-activated fly ash/slag paste and mortar at early ages. Cem Concr Compos 53:239-248

15. Gao X, Yu QL, Brouwers HJH (2016) Assessing the porosity and shrinkage of alkali activated slag-fly ash composites designed applying a packing model. Constr Build Mater 119:175-184

16. Ballekere Kumarappa D, Peethamparan S, Ngami M (2018) Autogenous shrinkage of alkali activated slag mortars: basic mechanisms and mitigation methods. Cem Concr Res 109:1-9

17. Sugama T, Brothers LE, Van de Putte TR (2005) Acidresistant cements for geothermal wells: sodium silicate activated slag/fly ash blends. Adv Cem Res 17(2):65-75 
18. Shayan A, Xu A (2006) Performance of glass powder as a pozzolanic material in concrete: a field trial on concrete slabs. Cem Concr Res 36(3):457-468

19. Spiesz P, Rouvas S, Brouwers HJH (2016) Utilization of waste glass in translucent and photocatalytic concrete. Constr Build Mater 128:436-448

20. Torres-Carrasco M, Puertas F (2017) Waste glass as a precursor in alkaline activation: chemical process and hydration products. Constr Build Mater 139:342-354

21. Vafaei M, Allahverdi A (2017) High strength geopolymer binder based on waste-glass powder. Adv Powder Technol 28(1):215-222

22. Puertas F, Torres-Carrasco M (2014) Use of glass waste as an activator in the preparation of alkali-activated slag. Mechanical strength and paste characterisation. Cem Concr Res 57:95-104

23. Martinez-Lopez R, Ivan Escalante-Garcia J (2016) Alkali activated composite binders of waste silica soda lime glass and blast furnace slag: strength as a function of the composition. Constr Build Mater 119:119-129

24. Shi Z, Shi C, Wan S, Li N, Zhang Z (2018) Effect of alkali dosage and silicate modulus on carbonation of alkali-activated slag mortars. Cem Concr Res 113:55-64

25. D EN (2009) Methods of testing cement-part 3: determination of setting times and soundness

26. BS EN (2005) Methods of testing cement-part 1: determination of strength, vol 3

27. Leemann A, Moro F (2017) Carbonation of concrete: the role of $\mathrm{CO}_{2}$ concentration, relative humidity and $\mathrm{CO}_{2}$ buffer capacity. Mater Struct Constr 50(1):1-14

28. Gao X, Yu QL, Brouwers HJH (2015) Reaction kinetics, gel character and strength of ambient temperature cured alkali activated slag-fly ash blends. Constr Build Mater 80:105-115

29. Puertas F et al (2018) Alkali-activated slag concrete: fresh and hardened behaviour. Cem Concr Compos 85:22-31

30. Fang G, Bahrami H, Zhang M (2018) Mechanisms of autogenous shrinkage of alkali-activated fly ash-slag pastes cured at ambient temperature within $24 \mathrm{~h}$. Constr Build Mater 171:377-387

31. Song S, Jennings HM (1999) Pore solution chemistry of alkali-activated ground granulated blast-furnace slag. Cem Concr Res 29(2):159-170

32. Yuan B, Yu QL, Brouwers HJH (2017) Assessing the chemical involvement of limestone powder in sodium carbonate activated slag. Mater Struct 50(2):136

33. Bernal SA, Provis JL, Myers RJ, San Nicolas R, van Deventer JSJ (2015) Role of carbonates in the chemical evolution of sodium carbonate-activated slag binders. Mater Struct 48(3):517-529

34. Garbev K, Beuchle G, Bornefeld M, Black L, Stemmermann P (2008) Cell dimensions and composition of nanocrystalline calcium silicate hydrate solid solutions. Part 1: synchrotron-based X-ray diffraction. J Am Ceram Soc 91(9):3005-3014

35. Garbev K, Bornefeld M, Beuchle G, Stemmermann P (2008) Cell dimensions and composition of nanocrystalline calcium silicate hydrate solid solutions. Part 2: X-ray and thermogravimetry study. J Am Ceram Soc 91(9):3015-3023

36. Kumar A et al (2017) The atomic-level structure of cementitious calcium silicate hydrate. J Phys Chem C 121(32):17188-17196
37. Toniolo N, Rincón A, Roether JA, Ercole P, Bernardo E, Boccaccini AR (2018) Extensive reuse of soda-lime waste glass in fly ash-based geopolymers. Constr Build Mater 188:1077-1084

38. Ismail I, Bernal SA, Provis JL, San Nicolas R, Hamdan S, van Deventer JSJ (2014) Modification of phase evolution in alkali-activated blast furnace slag by the incorporation of fly ash. Cem Concr Compos 45:125-135

39. Bernal SA, Provis JL, Rose V, Mejía de Gutierrez R (2011) Evolution of binder structure in sodium silicate-activated slag-metakaolin blends. Cem Concr Compos 33(1):46-54

40. Zhang S, Keulen A, Arbi K, Ye G (2017) Waste glass as partial mineral precursor in alkali-activated slag/fly ash system. Cem Concr Res 102:29-40

41. Marjanović N, Komljenović M, Baščarević Z, Nikolić V, Petrović R (2015) Physical-mechanical and microstructural properties of alkali-activated fly ash-blast furnace slag blends. Ceram Int 41(1):1421-1435

42. Fernández-Jiménez A, Palomo JG, Puertas F (1999) Alkaliactivated slag mortars: mechanical strength behaviour. Cem Concr Res 29(8):1313-1321

43. Fernández-Jiménez A, Puertas F, Sobrados I, Sanz J (2003) Structure of calcium silicate hydrates formed in alkalineactivated slag: influence of the type of alkaline activator. J Am Ceram Soc 86(8):1389-1394

44. Gonen T, Yazicioglu S (2007) The influence of compaction pores on sorptivity and carbonation of concrete. Constr Build Mater 21(5):1040-1045

45. Bakharev T, Sanjayan J, Cheng Y-B (2003) Resistance of alkali-activated slag concrete to acid attack. Cem Concr Res 33(10):1607-1611

46. Costa DG, Rocha AB, Souza WF, Chiaro SSX, Leitão AA (2012) Comparative structural, thermodynamic and electronic analyses of $\mathrm{ZnAlAn}^{-}$hydrotalcite-like compounds $\left(\mathrm{An}^{-} \mathrm{Cl}^{-}, \mathrm{F}^{-}, \mathrm{Br}^{-}, \mathrm{OH}^{-}, \mathrm{CO}_{3}{ }^{2-}\right.$ or $\left.\mathrm{NO}_{3}{ }^{-}\right)$: an ab initio study. Appl Clay Sci 56:16-22

47. Chen Y, Shui Z, Chen W, Chen G (2015) Chloride binding of synthetic $\mathrm{Ca}-\mathrm{Al}-\mathrm{NO}_{3} \mathrm{LDHs}$ in hardened cement paste. Constr Build Mater 93:1051-1058

48. Chen-Tan NW, van Riessen A, Ly CV, Southam DC (2009) Determining the reactivity of a fly ash for production of geopolymer. J Am Ceram Soc 92(4):881-887

49. Puertas F, Martínez-Ramírez S, Alonso S, Vázquez T (2000) Alkali-activated fly ash/slag cements: strength behaviour and hydration products. Cem Concr Res 30(10):1625-1632

50. Oh JE, Monteiro PJM, Jun SS, Choi S, Clark SM (2010) The evolution of strength and crystalline phases for alkali-activated ground blast furnace slag and fly ash-based geopolymers. Cem Concr Res 40(2):189-196

51. Torres-Carrasco M, Palomo JG, Puertas F, Puertas F (2014) Sodium silicate solutions from dissolution of glasswastes. Statistical analysis. Mater Constr 64(314):e014

52. Li N, Farzadnia N, Shi C (2017) Microstructural changes in alkali-activated slag mortars induced by accelerated carbonation. Cem Concr Res 100:214-226

Publisher's Note Springer Nature remains neutral with regard to jurisdictional claims in published maps and institutional affiliations. 